未来社会創造事業 探索加速型

「地球規模課題である低炭素社会の実現」領域

年次報告書(探索研究期間)

令和元年度採択研究開発代表者

\title{
[研究開発代表者名：笠井 大輔］
}

[国立大学法人長岡技術科学大学技学研究院・准教授]

[研究開発課題名：ゴム廃棄物を原料とした生分解性プラスチック生産］

実施期間： 令和 2 年 4 月 1 日～令和 3 年 3 月 31 日 


\section{§1. 研究開発実施体制}

(1) 研究代表者グループ (長岡技術科学大学)

(1)研究開発代表者:笠井 大輔 (長岡技術科学大学技学研究院、准教授)

(2)研究項目

•天然ゴム分解遺伝子変異株を用いたゴム変換系構築と反応条件の最適化

•天然ゴム分解菌のポリイソプレン分解遺伝子の特定とその機能欠損

•天然ゴム分解系の開発

\section{§2. 研究開発実施の概要}

本課題では、樹木成分の一つであるテルペン類、特にその中でも莫大な生産量を誇るポリイソ プレン(天然ゴム)を原料としたバイオマスプラスチック生産を目指す。具体的には、天然ゴムの主 成分であるポリイソプレンを分解できる微生物の酵素機能を利用して、土䁃や水環境における高い 生分解性と高い実用性が示されている“3-ヒドロキシ酪酸-3-ヒドロキシへキサン酸共重合ポリエステ ル $(\mathrm{PHBH}) ” の$ 生合成系の確立を目指している。

本年度は、ゴム分解菌 Nocardia sp. E1 株のポリイソプレン代謝中間体として得られるイソプレ ンオリゴマーの分解に関わる遺伝子の特定と遺伝子破壊を行なった。遺伝子破壊株の解析を行な った結果、ポリイソプレンの低分子化能に影響しないもののポリイソプレンでの生育能が低下したこ とから、本遺伝子の破壊によりイソプレンオリゴマーの分解能が低下したと結論した。

次に、ゴム分解菌 Rhizobacter gummiphilus NS21 株の細胞抽出液のガスクロマトグラフィー 分析を行い、本株が生産する PHA が 3-ヒドロキシ酪酸から構成されるポリヒドロキシ酪酸 (PHB) であることを明らかにした。さらに、PHB 蓄積量の増大を目指して PHB 分解に関与すると考えら れる遺伝子 (phaZ1 及び phaZ2)の遺伝子破壊株を作製した。 